\title{
PANTUN SEBAGAI BAHAN DAN TRADISI LOGIK MELAYU BERDASARKAN HUBUNGAN MAKNA PEMBAYANG-MAKSUD
}

\section{(Pantun a Source and Tradition of Malay Logic based on the Pembayang-Maksud Relationship)}

\author{
Tee Boon Chuan \\ teebc@utar.edu.my
}

Jabatan Pengajian Cina, Universiti Tunku Abdul Rahman (UTAR).

Sila rujuk: Tee Boon Chuan. (2021). Pantun sebagai bahan dan tradisi logik Melayu Berdasarkan hubungan makna pembayang-maksud. Melayu: Jurnal Antarabangsa Dunia Melayu, 14(2), 263-284. http://doi.org. 10.37052/jm.14(2)no6

\begin{tabular}{|llllll}
\hline $\begin{array}{l}\text { Peroleh: } \\
\text { Received: }\end{array}$ & $18 / 1 / 2021$ & $\begin{array}{l}\text { Semakan: } \\
\text { Revised }\end{array}$ & 8/4/2021 & $\begin{array}{l}\text { Terima: } \\
\text { Accepted: 28/5/2021 }\end{array}$ & $\begin{array}{l}\text { Terbit dalam talian: 2/7/2021 } \\
\text { Published online: }\end{array}$
\end{tabular}

\begin{abstract}
Abstrak
Hubungan makna antara unit pembayang dan maksud telah banyak dibincangkan oleh sarjana, namun belum lagi difahami sebagai hasil penaakulan analogi Melayu. Kekurangan ini akan ditangani dalam artikel ini yang tujuannya untuk membentuk penaakulan pantun agar dapat dikemukakan dan dijelaskan, sekali gus mengesahkan bahawa pantun ialah bahan dan tradisi logik Melayu dalam sejarah keilmuan Melayu. Keberadaan logik pantun dapat dibuktikan melalui keberadaan "pantun yang cukup elok" menurut pengelasan Za'ba, dan skopnya dicadangkan terdiri daripada lima, iaitu (1) peri alat tahu (yang mengungkapkan unit pembayang dan maksud), (2) peri objek tahu (isi unit pembayang dan maksud), (3) peri perbahasan atau kebolehanalogian (unit pembayang berhubungan secara analogi dengan unit maksud serta punca-punca kegagalannya), (4) peri penaakulan analogi (bentuk dan jenis analogi yang digunakan dalam penggubahan pantun), dan (5) peri falsafah penaakulan (justifikasi tentang keunikan dan kelebihan pantun bertaakul secara analogi). Berdasarkan pantun bertulis terawal dari tahun $1371 \mathrm{M}$, sejarah bertulis logik pantun secara khusus dan sejarah logik Melayu secara umum sepanjang 650 tahun dapat dibina semula menurut kerangka skop logik pantun yang dicadangkan artikel ini.
\end{abstract}

Kata kunci: pantun, taakul, analogi, logik, Melayu

(C) Dewan Bahasa dan Pustaka. 2021. This work is licensed under the term of the Creative Commons Attribution (CC BY) (http://creative commons.org/licenses/by/4.0/)

ISSN 1675-6460 e-ISSN 2682-8049 


\section{Abstract}

The relationship between the meaning of "pembayang" (or foreshadower) and "maksud" (or meaning) in pantun has been widely mentioned and discussed by scholars but not yet understood as a result of Malay analogical reasoning. These shortcomings are addressed in this article in order to clarify that the reasoning structure of pantun can be explained as a source and tradition of Malay logic in the Malay-Indonesian intellectual history. The existence of pantun logic can be proven by the existence of "well-made" pantun, according to Za 'ba's classification, and its proposed five scopes, namely: (1) the medium of knowing (i.e. how the units of "pembayang" and "maksud" are composed); (2) the knowing content (i.e. the scope of both units of "pembayang" and "maksud"); (3) the way of analogization (i.e. how "pembayang" can be analogized with "maksud" and the causes of their fallacies); (4) the varieties of analogy (i.e. the types and forms of analogy used in pantun composition), and; (5) the philosophy of logic (i.e. justification of the uniqueness and advantage of pantun logic through analogy). Based on the earliest evidence of pantun from $1371 \mathrm{CE}$, the written history of pantun logic for over 650 years until today could be rebuilt with the proposed scope of the study above.

Keyword: pantun, inference, analogy, logic, Malay

\section{PENDAHULUAN}

Pantun ialah puisi Melayu lama yang umumnya terdiri daripada empat baris ayat, dua baris pertama membentuk unit pembayang (atau sampiran) dan dua baris terakhir ialah unit maksud. Persoalan yang masih dan terus dibincangkan bahkan disifatkan sebagai "persoalan pokok bagi pantun" ialah sama ada pembayang perlu mempunyai hubungan makna dengan maksud (Mohd Taib, 1975: 4). Harun Mat Piah pernah memeriksa 1000 rangkap pantun yang akhirnya mendapati $25 \%$ mempunyai hubungan jelas, 30\% tidak sejelas hubungan, manakala $45 \%$ yang lain tidak mempunyai hubungan langsung (1989: 139). Oleh sebab yang demikian, sesetengah pengajian selepas ini kurang tegas dalam mengatakan perlunya pembayang berhubungan dengan maksud dalam pemantunan (Contoh Saludin, 2007: 21-22).

Perbezaan peratusan hubungan tersebut mempunyai implikasi besar terhadap logik khususnya penaakulan Melayu. Pembayang yang jelas atau tidak jelas hubungan dengan maksud boleh difahamkan sebagai berhubungan (sebanyak $25 \%+$ $30 \%=55 \%$ ) dan merupakan penaakulan analogi. Lihat contoh pantun berikut (setiap pantun diberikan nombor untuk rujukan dalam perbincangan.) 
1 Halia ini tanam-tanaman / Di barat sahaja akan tumbuhnya;

Dunia ini pinjam-pinjaman / Akhirat juga akan sungguhnya (142). ${ }^{1}$

Pembayang pantun ini berhubungan makna dalam erti kata pantun ini beranalogi lokasi (analogy by location) dengan maksud pantun: Halia hanya boleh tumbuh di barat (lokasi) adalah sepantun dengan tempat yang benar ("sungguh") bagi manusia adalah di akhirat. Dengan ini pantun ini telah melakukan suatu penaakulan lokasi daripada bidang perkebunan kepada bidang keagamaan. Contoh lain yang ada persamaan daripada golongan "pantun agama dan kepercayaan" adalah seperti yang berikut:

2 Anak ayam turun empat / Mati seekor tinggal tiga;

Supaya beroleh jalan makrifat / Baru terbuka pintu syurga. (191)

Hubungan makna pantun ini didapati agak sukar dijalinkan biarpun beberapa pendekatan telah dibuat:

i) Pendekatan perkiraan (berkira-kira): Empat menjadi tiga (pembayang) sedangkan jalan makrifat ialah jalan tunggal (bukan tiga) ke pintu syurga (maksud);

ii) Pendekatan sebab-akibat: Untuk mengatakan mati seekor (sebab) tinggal tiga (akibat) adalah sepantun dengan beroleh jalan makrifat (sebab) terbukalah pintu syurga (akibat) adalah sangat dangkal;

iii) Pendekatan fungsi: Jika fungsi jalan makrifat membukakan pintu syurga (maksud), jadi apakah fungsi "anak ayam turun empat" (pembayang) itu?

iv) Pendekatan lain (biarkan). ${ }^{2}$

Oleh yang sedemikian, pantun ini termasuk dalam fenomena "bunyi mengatasi makna”. Pembayang ini tidak berhubungan langsung dengan maksud, sekali gus tidak bersifat penaakulan dalam apa-apa jua bentuk. Bagi artikel ini, pantun yang berhubungan ialah pantun yang berbentuk penaakulan dan yang tidak berhubungan ialah pantun yang gagal, tiada jalan ketiga atau jalan tengah dalam perkara ini menurut pendekatan penaakulan.

Pantun yang terjalin hubungan antara pembayang dan maksud ialah pantun yang berjaya melakukan penaakulan analogi. Banyak contoh pantun berlainan tema yang berhubungan mencerminkan ciri penaakulan tersebut: 
3 Berek-berek turun ke semak / Dari semak turun ke padi;

Dari nenek turun ke mamak / Dari mamak turun ke kami. (32)

Pantun bertema "adat dan resam manusia" ini beranalogi darjah (analogy by degree) apabila berek-berek perlu turun ke semak-samun dahulu sebelum dapat memakan padi, iaitu semak-samun ialah peringkat yang mesti dilalui (pembayang) sepantun dengan nenek yang hendak sampai ke generasi kami juga perlu melalui peringkat mamak (maksud); contoh pantun lain yang bertemakan "jenaka dan permainan" juga taakulannya sedemikian:

4 Lapun dibawa orang menjaja / Datang dari Pulau Batu;

Budak kecil biasa manja / Mamak dahulu juga begitu. (426)

Pembayang dan maksud pantun ini terjalin atas analogi kualiti (analogy by characteristic quality), iaitu lapun ada kegunaannya sungguhpun perlu dibawa dari jauh (pembayang) ialah sepantun budak kecil bermanja (mesra) biarpun penjagaannya terkadang payah sedikit (maksud). Barangkali penaakulan analogi inilah yang menyebabkan pantun pada zaman dahulu dimengerti sebagai "laksana", "umpama" yang bermaksud "sepantun", iaitu "seperti", "macam", "seumpama" (menurut Kamus Dewan) yang membawa maksud yang sama dengan "analogi" yakni persamaan antara dua perkara yang berlainan.

Secara ringkasnya, pantun yang berhubungan antara pembayang-maksud ialah tanda pantun yang bertaakul analogi (analogical reasoning). Ketika pengkaji lepas membincangkan dan mempersoalkan tentang hubungan unit pembayang dengan unit maksud dalam sesebuah pantun (Mohd Taib, 1975: 4-12; Harun, 2007: ix-xi), perbincangan ini sebenarnya juga merupakan perbincangan yang boleh memberikan sumbangan kepada pengkajian penaakulan pantun. Oleh itu, perbincangan dan pengkajian pantun selama ini akan disusun dan dibina semula sebagai bahan penaakulan dan logik pantun sebagai pendekatan dalam artikel ini.

\section{PERMASALAHAN DAN OBJEKTIF KAJIAN: DEFINISI DAN SKOP LOGIK PANTUN}

Menurut kaedah pemantunan, apabila unit pembayang berhubungan makna dengan unit maksud dalam pantun maka suatu pemindahan atau penerokaan makna secara analogi dari dunia luaran ke dunia dalaman berlaku. Menurut Muhammad Haji 
Salleh, dunia luaran ialah dunia alam persekitaran fizikal pemantun sedangkan dunia dalaman ialah dunia emosi, akal, nilai dan mimpi pemantun atau manusia itu sendiri (Muhamad, 2016: 56-57). Dunia luaran menjadi sumber isi unit pembayang dan dunia dalaman merupakan sumber isi unit maksud, dan kedua-dua isi unit hendaklah ada hubungan "analogi dan ibarat", iaitu "bahagian-bahagian alam seperti menawarkan padanan atau bayangan persamaan untuk situasi atau pengalaman yang sedang dihadapinya" oleh pemantun (Muhamad, 2016: 106-107). Sesungguhnya "padanan atau bayangan persamaan" itu tidak lain bermaksud "analogi" dan pemindahan dari dunia alam ke dunia kejiwaan merupakan suatu penaakulan beranalogi yang menjadi teras penaakulan pantun.

Dengan pengertian yang sedemikian, logik pantun boleh disifatkan sebagai suatu tradisi penaakulan yang terdiri daripada dua unit, iaitu unit pembayang dari dunia alam (luaran) bagi menemukan kesepadanan makna unit maksud yakni dari dunia dalaman manusia (dalaman). Proses ini dapat dihuraikan lebih teliti untuk penjelasan seperti yang berikut:

i) Domain: Unit pembayang ialah domain sumber, manakala unit maksud ialah domain sasaran;

ii) Tahu: Domain sumber ialah dunia alam yang sudah diketahui, sedangkan domain sasaran ialah dunia inderawi atau kejiwaan yang menantikan suatu pemakluman;

iii) Kesepadanan: Kedua-dua domain dapat dihubungkaitkan kerana terdapat persamaan aspek tertentu (x menurut formula berikut);

iv) Formula: Domain sumber mempunyai / adalah $\mathrm{x}$, dan begitu A berlaku; domain sasaran juga mempunyai / adalah $\mathrm{x}$, jadi A juga harus berlaku (Tittle, 2011: 296);

v) Penaakulan: Tujuan penaakulan adalah untuk menemui dan memaklumkan A daripada domain sasaran berdasarkan pengetahuan domain sumber yang masing-masing mempunyai persamaan $\mathrm{x}$.

Sebagai contoh, daripada pantun 1 di atas, penaakulan pantun tersebut berbentuk:

vi) Domain: Unit pembayang / domain sumber daripada bidang perkebunan, unit maksud / domain sasaran daripada bidang keagamaan;

vii) Tahu: Halia sudah diketahui hanya boleh bertumbuh pesat di tempat "barat", sedangkan tempat "sungguh" manusia belum lagi diketahui; 
viii) Kesepadanan: Halia tumbuh mesti ada tempatnya (iaitu di "barat"), manusia kekal juga mesti ada tempatnya;

ix) Formula: Jika "barat" itu tempat halia tumbuh, maka di mana tempat manusia itu beroleh "sungguh"?

x) Penaakulan: "di barat sahaja akan (halia) tumbuhnya," dan atas pedoman pada ilmu agama, "akhirat juga (manusia) akan sungguhnya."

Seperti yang sudah dimaklumi, penaakulan sedemikian ialah penaakulan berbentuk analogi yang luas digunakan dalam bidang sains tulen, matematik, undang-undang sehinggalah dalam bidang kognitif kreatif dan penyelesaian masalah seharian (Holyoak, 2012: 235). Dengan erti kata yang lain, penaakulan analogi pantun bukanlah sesuatu yang ganjil atau boleh diuar-uarkan sebagai "kearifan lokal" kerana pantun merupakan fenomena sejagat pemikiran manusia. Sebaliknya, kearifan lokal terserlah pada cara orang Melayu menstrukturkan penaakulan analogi ini dalam suatu bentuk atau genre pantun sejak turun-temurun yang membezakannya daripada puisi empat baris berima lain di dalam dunia yang diketahui umum.

Masalahnya, walaupun hubungan pembayang-maksud serta kaedah menghubungkan kedua-dua unit pembayang-maksud pantun telah banyak dibincangkan dan dijelaskan oleh sarjana termasuk Mohd. Taib, Harun, Muhamad dan lain-lain yang akan diwacanakan, namun belum ada kesedaran bahawa hubungan tersebut sebenarnya merupakan penaakulan analogi sekali gus logik pantun Melayu. Objektif artikel ini bukanlah sekadar menjelaskan hubungan pembayang-maksud sebagai suatu bentuk penaakulan analogi yakni logik pantun Melayu, bahkan definisi dan skop penaakulan analogi pantun juga akan dihuraikan dan dikemukakan.

Biarpun penaakulan merupakan teras kepada logik, namun logik pantun yang sedia dibina dalam artikel ini mempunyai skop yang lebih luas lagi menyeluruh. Logik India menurut Nyaya-Sastra terdiri daripada lima bahagian, iaitu tentang (i) alat tahu (pramana), (ii) objek tahu (prameya), (iii) perbahasan (vada), (iv) penaakulan (avayava) dan (v) pro- dan kontra- antara tradisi logik (Vidyabhusana, 1921: 50-51). Logik Barat pula menurut Organon karya Aristotle (384 SM-322 SM) merangkumi (i) kategori, (ii) proposisi, (iii) silogisme, (iv) hukum-hukum pemikiran, (v) klasifikasi sains atau keilmuan, (vi) retorik dan lain-lain (Spangler, 1987). Begitu juga dengan logik Arab-Islam dan China yang sesungguhnya tidak terhad pada penaakulan (Street, 2004: 523-596; Needham, 1998). Dalam perkara ini, skop logik pantun akan dibina menurut kerangka Nyaya-Sastra yang lebih bersifat asas dan umum, sedangkan kerangka Organon Aristotle lebih mendalam dan memerlukan 
penganalisisan yang lebih sistematik sebelum pantun dihuraikan secara berkesan lagi memuaskan.

\section{SKOP LOGIK PANTUN I: PERI ALAT TAHU}

Seperti yang telah dijelaskan berdasarkan objektif kajian tersebut, logik pantun berteraskan penaakulan analogi daripada domain sumber yang telah diketahui kepada domain sasaran lain yang belum diketahui. Penjelasan ini mengandaikan bahawa kedua-dua domain itu dapat diketahui menurut kemampuan manusia. Maka dua skop logik yang dicadangkan Nyaya-Sastra terlebih dahulu berperikan alat tahu dan objek tahu adalah sangat mendasar dan mendahului skop-skop lain dalam pembinaan logik pantun Melayu. Peri alat tahu adalah untuk menjawab apaapa yang ada pada manusia untuk mendapat tahu daripada kedua-dua domain yang bakal diungkapkan sebagai unit pembayang dan maksud dalam pantun. Empat alat tahu cadangan Nyaya-Sastra ialah alat persepsi (pancaindera), alat taakul (akal), alat perumpamaan (akal) dan alat sabda (ilmu agama yang biasanya di luar batas akal dan pancaindera) masing-masing boleh diambil sebagai kerangka pemeriksa bagi menentu dan mengesan keadaan pantun Melayu bagi skop logik cadangan ini.

Suatu fenomena yang dapat diperhatikan sepanjang pemantunan ialah unit pembayang pantun cenderung diungkapkan melalui pancaindera khasnya inderia mata dan tangan (atau badan) sedangkan unit maksud lebih kepada akal. Alat tahu ketiga-tiga contoh pantun di atas (kecuali pantun 2 yang gagal) dapat diringkaskan seperti yang berikut:

i) Unit pembayang pantun 1, iaitu "Halia ini tanam-tanaman / Di barat sahaja akan tumbuhnya" merupakan tahu inderia mata (menjurus kepada pertimbangan akal) dan unit maksud "Dunia ini pinjam-pinjaman / Akhirat juga akan sungguhnya" ialah tahu sabda yang menyatakan keberadaan akhirat hanya boleh mendapat sokongan daripada kitab agama;

ii) Unit pembayang pantun 3, iaitu "Berek-berek turun ke semak / Dari semak turun ke padi" ialah tahu inderia mata manakala unit maksud "Dari nenek turun ke mamak / Dari mamak turun ke kami" merupakan tahu akal;

iii) Unit pembayang pantun 4, iaitu "Lapun dibawa orang menjaja / Datang dari Pulau Batu" ialah tahu inderia mata menurut orang yang memerhatikan dan unit maksud "Budak kecil biasa manja / Mamak dahulu juga begitu" ialah tahu akal dalam bentuk perumusan. 
Ketiga-tiga contoh pantun di atas mengesahkan bahawa pancaindera, akal dan sabda ialah tiga alat tahu yang membolehkan manusia mendapat tahu tentang dunia alam dan dunia dalaman manusia. Peri alat perumpamaan dibezakan daripada alat taakul yang dinisbahkan kepada akal memerlukan beberapa penjelasan lanjut yang diperturunkan seperti yang berikut:

i) "Perumpamaan" memang termasuk dalam satu bentuk penaakulan dan diasingkan bagi memberi maksud bahawa alat taakul merangkumi semua bentuk penaakulan berdeduktif atau induktif kecuali perumpamaan;

ii) Alat taakul yang dimaksudkan tidak semestinya merujuk kemampuan manusia menaakul daripada domain sumber kepada domain sasaran, alat taakul boleh sesama domain daripada unit pembayang atau maksud sahaja:

5 Apa guna berkain batik / Kalau tidak dengan sujinya;

Apa guna beristeri cantik / kalau tidak dengan budinya. (206)

Unit pembayang ialah tahu pancaindera mata (menjurus kepada akal) yang merupakan singkatan penaakulan daripada yang berikut:

(a) Kain batik biasanya bersuji (berbunga);

(b) Kain batik ini didapati tidak bersuji;

(c) Rumusan: "Apa guna berkain batik / Kalau tidak dengan sujinya"?

Unit maksud (tahu akal) juga sesama domain dan merupakan singkatan struktur penaakulan yang sama dari penaakulan akal;

iii) Dalam konteks pantun Melayu, alat taakul merujuk penaakulan sesama domain, sedangkan alat perumpamaan ialah penaakulan antara domain, iaitu dari domain alam ke domain dalaman manusia;

Sebagai rumusan, keempat-empat alat tahu tersebut di atas mendapat sokongan pantun yakni dapat menjelaskan keadaan alat tahu pantun. Namun begitu, penelitian lanjut perlu dijalankan bagi mengenal pasti alat tahu pantun sama ada terhad pada empat jenis atau ada yang tidak teramal atau terkeluar daripada kerangka NyayaSastra. 


\section{SKOP LOGIK PANTUN II: PERI OBJEK TAHU}

Jika skop alat tahu kurang diperhatikan dan dibincangkan oleh pengkaji pantun sebelum ini, skop kedua logik pantun berkenaan dengan objek tahu yang memang mendapat perhatian hangat daripada para pengumpul dan peneliti pantun. Jika objek tahu yang dicadangkan Nyaya-Sastra termasuk tahu berkenaan "jiwa, badan, inderia, objek inderia, intelek, budi, aktiviti, kesalahan, transmigrasi, hakikat, kedukaan dan perlepasan" (Vidyabhusana, 1921: 51), maka pantun ini didekati oleh para peminat tempatan khususnya melalui pengelasan tema dan isi pantun. Oleh sebab itu, artikel ini tidak akan membincangkan skop ini melainkan mengemukakan beberapa ulasan untuk penambahbaikan pengelasan sedia ada.

Pengelasan tema dan isi pantun yang terlalu longgar dan kasar sudah tentu tidak dapat memenuhi keperluan bagi penjelasan tentang skop objek tahu ini. Menurut Harun, salah seorang pelopor pengajian pantun, iaitu Van Ophuijsen pernah mengelaskan tema pantun kepada lima "macam atau jenis" iaitu (i) pantun tua, (ii) pantun dagang, (iii) pantun riang, (iv) pantun nasihat dan (v) pantun muda (Harun, 1989: 161) yang telah mencampuradukkan pengelasan umur dan bukan umur, sudah tentu tidak sehalus dan seragam pengelasan yang dikembangkan kemudian oleh Zainal Abidin Bakar seperti berikut:

i) Pantun adat dan resam manusia

ii) Pantun agama dan kepercayaan

iii) Pantun budi

iv) Pantun jenaka dan permainan

v) Pantun teka-teki

vi) Pantun kepahlawanan

vii) Pantun pendidikan dan nasihat

viii) Pantun peribahasa dan perbilangan

ix) Pantun kias dan ibarat

x) Pantun kembara dan perantauan

xi) Pantun percintaan (Zainal Abidin, 1983: 31)

Pengelasan tema yang lebih tersusun dan rapi dapat memberikan gambaran menyeluruh tentang skop tahu yang mampu dan sedia diungkapkan oleh pemantun melalui kedua-dua domain sumber dan sasaran yang merangkumi dunia alam persekitaran dan dunia dalaman manusia. 
Namun begitu, pengelasan tema dan isi pantun selama ini lebih berdasarkan kepada makna atau mesej unit maksud. Seperti yang telah diketahui, penaakulan analogi pantun boleh berfungsi hanya melalui dua domain yang berasingan, iaitu domain sumber dari dunia alam dan domain sasaran dari dunia dalaman manusia. Tanpa maklumat dan bimbingan tahu daripada domain sumber, iaitu unit pembayang, penemuan dan penerokaan makna domain sasaran atau unit maksud tidak akan berjaya, sekali gus penaakulan analogi boleh menjadi gagal. Oleh sebab yang demikian, penjelasan skop objek tahu pantun perlu mengambil kira keadaan domain sumber atau unit pembayang secara berasingan. Jika pancaindera sudah menjadi alat tahu pemantun, maka apakah objek inderia yang boleh diungkapkan seperti unitunit pembayang daripada contoh-contoh pantun 1, 3 dan 4 di atas? Dan selanjutnya apakah pengelasan tema yang boleh dibuat berdasarkan keseluruhan tahu unit pembayang pantun yang telah dikumpulkan dan diamati? Dengan erti kata yang lain, apakah "falsafah alam pantun Melayu" itu menurut perbahasan Muhammad Haji Salleh (Muhamad, 2016: 104-108)?

Berdasarkan pengulasan yang dihuraikan di atas, perbincangan dan pengelasan tema serta isi pantun daripada para pengumpul dan peneliti pantun selama ini masih tidak mampu menampung keperluan skop objek tahu untuk membolehkan logik pantun dibangunkan semantap logik India, Barat dan lain-lain yang telah diketahui.

\section{SKOP LOGIK PANTUN III: PERI PERBAHASAN ATAU KEBOLEHANALOGIAN}

Skop ketiga logik pantun adalah berkenaan dengan beberapa pokok perbahasan tentang kebelohanalogian pembayang-maksud yang terdiri daripada dua domain yang berasingan, atau keberkesanan penaakulan analogi pantun. Peri ada atau tidaknya hubungan antara unit pembayang dan maksud senantiasa diulangi sebagai suatu persoalan utama pantun (Harun, 2007: ix), akan bertukar bentuk persoalan menjadi penaakulan pantun yang berjaya (berhubungan) atau gagal (tiada berhubungan) dalam konteks kelogikan. Begitu juga jika kaedah pemantunan yang diutarakan menurut ukuran kesusasteraan dan kesenian, maka kaedah tersebut akan dibincangkan sebagai kaedah penaakulan menurut bidang logik atau keilmuan. Skop logik pantun ketiga ini akan membahaskan perkara utama antara lain termasuklah definisi dan ukuran analogi, beza analogi daripada penaakulan induktif (inductive reasoning), kebolehanalogian antara dunia alam dan dunia dalaman manusia, di samping penaakulan analogi yang berkesan dan penaakulan analogi yang gagal. Tujuan perbahasan berkaitan dengan perkara ini tidak lain adalah untuk menjelaskan 
dan memastikan kedua-dua unit pembayang-maksud pantun dapat ditaakul menepati bentuk analogi dengan cara yang tepat lagi berkesan.

Selayang pandang, penaakulan analogi dalam bentuk pantun tidaklah semudah seperti yang dijangka seperti dapatan sarjana lepas yang mengatakan bahawa 45\% daripada karya tersebut tidak mampu menjalinkan suatu hubungan makna antara unit pembayang dan maksud, manakala $30 \%$ yang lain dikatakan tidak sejelas hubungan tersebut. Sungguhpun formula penaakulan analogi pantun dapat dirumuskan (berdasarkan kaedah pemantunan yang disepakati sarjana kesusasteraan) sebagai "domain sumber mempunyai / adalah $\mathrm{x}$, dan begitu A berlaku; domain sasaran juga mempunyai / adalah $\mathrm{x}$, jadi A juga harus berlaku," namun kebolehanalogian pembayang-maksud pantun juga banyak diabaikan oleh pemantun selama ini.

Pengabaian umum biasanya bermula daripada kecenderungan pemantun berpantun dalam satu-satu domain yakni kebolehanalogian antara dua domain tidak kesampaian. Lihat beberapa contoh yang dimaksudkan dalam pantun berikut:

6 Banyak bulan perkara bulan / Tidak semulia bulan puasa; Banyak Tuhan perkara Tuhan / Tidak semulia Tuhan Yang Esa. (123)

7 Menulis surat di dalam gelap / Hurufnya salah banyak tak kena; Jagalah diri jangan silap / Jikalau silap dapat bencana. (727)

Kedua-dua rangkap pantun ini memang memenuhi formula penaakulan pantun dalam erti kata:

6 Bulan puasa adalah bulan agama (" $x$ ") dan merupakan bulan termulia; Tuhan Yang Esa adalah tuhan agama ("x") dan merupakan tuhan termulia.

7 Menulis dalam keadaan gelap ("x") menjadikan huruf banyak salah; Menjaga diri dengan cara "gelap" ("x") menyebabkan kelakuan banyak silap.

Namun begitu, penaakulan tersebut di atas adalah sesama domain kerana "bulan" unit pembayang 6 merujuk bulan kalendar dan bukannya bulan alam (domain alam), sedangkan unit pembayang 7 merujuk kelakuan manusia yang sama dengan unit maksud yakni berdomainkan kelakuan manusia yang sama. Bagi penaakulan ala persamaan sesama domain merupakan penaakulan induktif (inductive reasoning) secara umum, sedangkan penaakulan pantun dinisbahkan suatu penaakulan induktif yang mengkhusus, iaitu berdasarkan persamaan antara domain yakni domain sumber (dunia alam) dan domain sasaran (dunia dalaman manusia) yang dinamai 
sebagai penaakulan analogi (Holyoak, 2012: 234). Dengan kata lain, pengabaian kerap berlaku apabila pemantun menyalahertikan penaakulan analogi pantun dengan penaakulan induktif umum yang lain sehingga terkeluar daripada kaedah pantun yang ditetapkan.

Pengabaian kedua ialah kesepantunan antara dua domain dalam pantun tidak terjalin dengan baik. Jenis pantun ini biasanya memang berdomainkan dunia alam sebagai unit pembayang, dan domain dalaman manusia sebagai unit maksud, namun tiada hubungan makna yang boleh dianalogikan seperti contoh berikut:

8 Hujan turun serintik dua rintik / Tumbuh cendawan dua kaki;

Tuan bersaudara dua beradik / Mana pergi seorang lagi? (582)

9 Pohon manggis pohon embacang / Ketiga dengan pohon lulita;

Duduk menanggis abang pincang / Katanya jalan tidak rata. (1215)

Kedua-dua unit pembayang 8 dan 9 didapati sukar untuk dihubungkaitkan, sama ada makna harfiah atau metaforanya dengan makna unit maksud seperti yang berikut:

8 jika bermaksud "sebab-akibat" (hujan turun, cendawan tumbuh), maka apakah kaitannya dengan dua beradik tinggal seorang di sini? ATAU

Jika bermaksud "tumbuh cendawan dua kaki", apakah yang hendak dimetaforakan "dua" ini dengan "dua beradik" daripada unit maksud tersebut?

9 kedua-dua makna harfiah atau metafora yang mengutarakan keberanekaan pohon boleh memincangkan adalah tidak jelas, dan kebolehkaitannya dengan kepincangan unit maksud (“jalan tidak rata") juga tidak jelas.

Kegagalan contoh tersebut di atas ialah tiada hubungan " $x$ " menurut formula penaakulan pantun biarpun pantun tersebut memenuhi keperluan dua domain berasingan dari dunia alam dan dunia dalaman manusia yang menjadi salah satu tumpuan utama perbahasan skop logik pantun ini.

Tujuan yang lebih positif daripada skop perbahasan ini adalah untuk mengesan dan mendirikan contoh serta hukum penaakulan analogi pantun. Beberapa contoh pantun dapat dijadikan bahan penjelasan adalah seperti yang berikut:

10 Bunga Cina di atas batu / Jatuh daunnya ke dalam ruang; Adat dunia memang begitu / Sebab emas budi terbuang. (203) 
11 Buah cempedak di luar pagar / Ambil galah tolong jolokkan;

Saya budak baharu belajar / Mana yang salah tolong tunjukkan. (543)

Kedua-dua rangkap pantun 10 mempunyai kesepantunan makna, iaitu "mahu bunga, daun dibuang / mahu emas, budi dibuang" yang mana persamaan " $x$ " adalah "mengutamakan sesuatu dan yang lain dibiarkan." Pantun 11 pula, jelas bahawa persamaan " $x$ " ialah "orang baharu memerlukan bimbingan" sama ada dari segi perkebunan (domain sumber) ataupun pembelajaran (domain sasaran). Bahkan keberkesanan pemantunan sekali gus penaakulan kedua-dua rangkap pantun ini membolehkan kita mengenal pasti bentuk analogi yang digunakan, iaitu analogi "sebab-akibat" (pantun 10) dan analogi "pelakon-aksi" (pantun 11).

Melalui contoh serta penjelasan tersebut atas, jelaslah bahawa tujuan skop ketiga logik pantun ini antara lain adalah untuk mengenal pasti dan mendirikan hukum unit pembayang serta sebab kegagalannya, hukum kebolehanalogian pembayangmaksud berserta punca yang menggagalkannya dan sebagainya.

\section{SKOP LOGIK PANTUN IV: PERI BENTUK ANALOGI}

Skop logik pantun yang tidak kurang dari segi keutamaannya ialah pengkajian tentang persamaan " $x$ " menurut formula yang membolehkan penaakulan analogi pembayang-maksud atau dua domain berasingan dilakukan. Jika kajian menyeluruh tentang metafora Melayu belum lagi dilakukan menurut pemerhatian Hassan Ahmad (Hassan, 2016: 145), ${ }^{3}$ kajian yang juga menantikan suatu penelitian setimpal daripada para peminat pantun adalah tentang jumlah, jenis serta kategori analogi yang cenderung digunakan oleh para pemantun selama ini. Dalam perkara ini, Nyaya-Sastra telah menghuraikan sebanyak 24 bentuk analogi (atau "jati" menurut konsep Sanskerta yang telah diserap ke dalam bahasa Melayu) tidak melewati kurun kedua Masihi. Maka skop keempat logik pantun ini adalah wajib bagaikan suatu dinding yang bakal membangunkan kajian logik pantun sebuah rumah yang berasas lagi kukuh. Penghuraian berikut bukanlah suatu pengkajian lengkap tentang bentuk analogi pantun melainkan suatu penjelasan tentang keberadaan bentuk-bentuk analogi yang ditaakulkan sepanjang pemantunan Melayu. Oleh itu bentuk-bentuk analogi yang bakal dihuraikan sekadar beberapa contoh umum sahaja daripada senarai lengkap. Bentuk-bentuk analogi umum yang dimaksudkan antara lain termasuklah: 
i) Analogi sinonim (analogi sama erti)

12 Cahaya malam gilang-gemilang / Kerana disinar bulan purnama;

Gajah mati meninggalkan tulang / Manusia mati meninggalkan nama. (645)

13 Tinggi-tinggi pokok lembari / Sayang pucuknya menyapu awan;

Habis teluk puas kucari / Bagai punai mencari kawan. (1220)

Pantun 12 juga boleh berbentuk analogi objek-kesan menurut makna yang hendak disinonimkan: setiap objek ada kesannya masing-masing, bulan purnama meninggalkan sinar gilang-gemilang, dan gajah meninggalkan tulang dan manusia meninggalkan nama; pantun 13 juga berbentuk analogi pelakon-aksi bagi maksud payahnya pucuk (daun baharu) hendak menyapu awan adalah sama payahnya hendak mendapat kawan di teluk.

ii) Analogi antonim (analogi lawan erti)

14 Hilir dari Bengkahulu / Singgah menjala di bulan terang;

Bagaimana jong nak lalu / Kalau sudah dilingkung karang? (945)

15 Minyak ketiau tumpah di lantai / Buah mempelam saya longgokkan;

Di Tanah Riau baju dipakai / Di Tanah Jambi baju diburukkan. (1211)

Kedua-dua makna unit pembayang 14 dan 15 adalah berlawanan makna dengan unit maksud: "singgah menjala" ialah tindakan sukarela diri sedangkan jong terpaksa bersinggah kerana "dilingkung karang"; begitu juga minyak ditumpah lawan minyak dilonggok, dan baju dipakai lawan dengan baju yang diburukkan.

iii) Analogi sebab-akibat

16 Bunga berembang jatuh ke pantai / Diambil orang bawa ke Pekan;

Begitu nasib kain cindai / Kerana cantik menjadi cagaran. (948)

17 Gelang emas di atas peti / Ambil lampu padam pelita;

Barulah puas rasanya hati / Jika dapat bertentang mata. (1421)

Kedua-dua pantun 16 dan 17 mempunyai struktur makna "sebab-akibat" yang sama, iaitu sebab bunga berembang dan kain cindai dihargai maka mempunyai akibat ("nasib") yang lebih baik, atau sumber diperbaiki(lampu menerang; bertentang mata) sasaran pun tercapai (keemasan gelang terlihat; kepuasan hati terkabul). 


\section{iv) Analogi lokasi}

18 Anak beruk turun ke tanah / Hendak mencari buah pisang;

Banyak pokok tumbuh di tanah / Dedalu api tumbuh di batang. (946)

19 Buah ketupat bekal bertenun / Jatuh sebiji di atas tikar;

Di mana adik kita bertemu / Di bawah pokok tepi belukar. (1440)

Kedua-dua rangkap pantun ini berfokus pada suatu lokasi: "ke tanah" (mencari buah pisang), "di batang" (dedalu api bertumbuh), "di atas tikar" (buah ketupat jatuh) dan "di bawah pokok" (tempat kita bertemu) yang merupakan penaakulan analogi berlokasi masing-masing.

\section{v) Analogi kualiti}

20 Di sana padi di sini padi / Itulah nama sawah dan bendang;

Di sana budi di sini budi / Barulah sempurna bernama orang. (240)

21 Apa guna padiku ini / Sini sangkut sana pun goyang;

Apa guna hatiku ini / Sini sangkut sana pun sayang? (1414)

Kedua-dua pantun atas ada berkaitan dengan sesuatu kualiti: sawah, bendang bergantung kepada padi dianalogikan dengan manusia kepada hati, sedangkan kedua-dua padi dan hati dalam berkeadaan ketergantungan ("tersangkut").

vi) Analogi darjah

22 Perahu baharu temberang pun baharu / Baharu sekali masuk Melaka; Abang baharu, adik pun baharu / Baharu sekali kenal biasa. (1403)

23 Bukan kacang sebarang kacang / Kacang melilit kayu jati;

Bukan datang sebarang datang / Datang melihat jantung hati. (1433)

Kedua-dua rangkap pantun ini berdarjahkan suatu tingkatan "lembab-hangat" ("baharu" bermetaforakan makna "penuh ghairah") atau "longgar-erat" yakni bermakna "bukan hangat sebarang hangat" (22) atau "bukan erat sebarang erat" (23) dalam hubungan percintaan khasnya. 
vii) Analogi fungsi

24 Apa guna kepuk di ladang / Kalau tidak berisi padi?

Apa guna berambut panjang / kalau tidak berani mati? (608)

25 Layang-layang di atas bukit / Kayu tengar dari seberang;

Cinta sayang bukan sedikit / Racun penawar tuan seorang. (1440)

Kedua-dua rangkap pantun ini beranalogi dengan fungsi dalam erti kata kepuk perlu berisikan padi, laki-laki perlu berani mati, dan kayu tengar untuk membuat layang-layang, manakala "tuan seorang" sebagai racun penawar cinta sayang.

Selain bentuk-bentuk analogi yang dihuraikan di atas, memang terdapat banyak lagi bentuk analogi yang boleh ditemui. Contoh pantun penaakulan termasuklah analogi pelakon-aksi dan analogi objek-kesan yang telah disebutkan sebelum ini. Keberanekaan dan keberadaan penaakulan analogi pantun setakat ini sudah cukup dan mampu untuk membuktikan bahawa pantun memerlukan suatu pengkajian dan pemeriksaan menyeluruh sekali gus memantapkannya sebagai skop keempat logik pantun Melayu yang kukuh.

\section{SKOP LOGIK PANTUN V: PERI FALSAFAH LOGIK PANTUN}

Skop kelima dan terakhir logik pantun adalah berkaitan dengan perkara falsafah, iaitu penjelasan bahkan pertahanan sifat logik pantun Melayu yang berlainan daripada logik tradisi dunia yang lain. Kelainan atau keunikan logik pantun Melayu antara lainnya dapat dirumuskan seperti yang berikut:

i) Penaakulan pantun berbentuk analogi dan bukan berbentuk deduktif atau induktif;

ii) Proses penaakulan analogi pantun Melayu terdiri daripada dua unit atau peringkat, iaitu pembayang ke maksud (ini hanya bersamaan dengan logik Buddha ala Dharmakirti yang telah dikenali masyarakat Sriwijaya sekitar 691M), sedangkan logik Buddha tiga peringkat, logik Hindu termasuk Nyaya-Sastra mencadangkan lima peringkat dan sebagainya;

iii) Penaakulan analogi pantun mewajibkan kebolehanalogian daripada dua domain yang berasingan, iaitu domain sumber dari dunia alam dan domain sasaran dari dunia dalaman manusia; 
Keunikan bahkan kelebihan bentuk penaakulan sedemikian menuntut suatu penjelasan falsafah (kerana perkara-perkara atas begitu mendasar kepada struktur logik pantun Melayu) yang mampu menjernihkan kekeliruan yang mungkin berbangkit daripada logik India, Barat, China, Islam dan lain-lain. Hal inilah antara tugas dan matlamat skop kelima yang diperjelas dan dipertanggungjawabkan menurut Nyaya-Sastra yang menjadi kerangka penghuraian artikel ini.

Bagi maksud percontohan skop, perkara ketiga di atas akan dikupas sekadar menjelaskan tentang skop logik yang dimaksudkan. Kebanyakan sarjana tempatan bermula dengan Za'ba, seterusnya Muhammad Haji Salleh, sehingga sekarang memperkatakan kebolehanalogian pantun ini dalam konteks metafora:

i) Za'ba pernah memberikan makna "pantun" pada dahulu kala yang difahami sebagai "seperti" atau "umpama" (Za'ba, 2002: 223). Ketika membahaskan metafora atau "bahasa kiasan", Za 'ba menjelaskan bahawa syarat metafora "hendaklah kedua benda yang dibandingkan itu berlainan, hanya serupa pada satu-satu perkara yang tertentu sahaja", dan perbandingan sesama benda (iaitu sesama domain) bukan metafora dan "tidaklah boleh dipakai 'laksana' atau 'seumpama' pada perbandingan yang demikian" (Za'ba, 2002: 197). Maksud Za'ba ini jelas memperkatakan bahawa pantun ialah "umpama" yakni "perbandingan antara keserupaan dua benda" dan merupakan "bahasa kiasan" atau "metafora";

ii) Hassan Ahmad percaya bahawa metafora ialah sistem kognitif manusia sejagat dan "pantun Melayu merupakan contoh terbaik untuk mengkaji struktur pemikiran atau struktur kognitif Melayu" yang menurutnya juga terserlah melalui kebolehanalogian melalui unit pembayang dan unit maksud pantun (Hassan, 2016: 118, 128-132);

iii) Muhammad Haji Salleh banyak menghuraikan "keserupaan, kesamaan, pertindihan, dan keselarian antara hal yang berlaku dalam alam dan pada diri manusia secara peribadi atau kelompok. Hal inilah yang dikutip untuk dibina analogi, misalan, teladan, tetapi juga sebagai bayangan/pembayang" pantun, dan kesemua ini disifatkan sebagai "perayaan metafora" (Muhamad, 2016: 67-92);

Masalah boleh berbangkit ekoran daripada penjelasan sedemikian ialah: kebolehanalogian domain alam dan domain dalaman manusia itu suatu metafora (kiasan) semata-mata, atau kebolehanalogian ini sebenarnya mencerminkan suatu 
kesatuan alam-manusia yang telah banyak dibuktikan oleh adanya persamaan antara kualiti, fungsi, sebab-akibat, darjah dan sebagainya menurut skop keempat yang telah dinyatakan atas. Secara ringkasnya, kesatuan alam-manusia ini merupakan suatu andaian (bersifat metafora, kiasan) atau suatu kebenaran? Hal inilah antara perkara yang perlu diperdalam sebelum falsafah logik pantun Melayu dapat diperkatakan atau dipertahankan di hadapan dunia logik yang terdiri ahli-ahli logik India, Barat, China, Islam dan lain-lain dari serata dunia.

\section{KESIMPULAN}

Za'ba (begitu juga Mohd Taib, 1975: 8) pernah memberikan pandangannya tentang persoalan sama ada perlu atau tidaknya hubungan antara unit pembayang dengan unit maksud dalam sesebuah pantun. Menurut $\mathrm{Za}$ 'ba, "sebenarnya tiada perkaitan itu tidak mengapa, kerana pembayang itu tidak termasuk ke dalam tujuan pantun itu yang sebenar" yakni tidak menjejaskan sesebuah pantun yang boleh dinilai sebagai pantun "elok". Namun begitu, Za 'ba mengulas lagi bahawa "jika pantun yang cukup elok boleh dilihat pembayangnya memang mengandungi maksud itu dengan cara kias dan bayangan diambilnya kepada gambaran alam dan sebagainya" (Za'ba, 2002: 226-227). Perbezaan antara pantun elok dan pantun "cukup elok" itu bukan sekadar memutuskan fungsi hubungan pembayang-maksud dalam pantun, bahkan telah mengesahkan bahawa pantun-pantun yang "cukup elok" ini adalah berhubungan sekali gus memberi sumbangan kepada perkembangan dan pensejarahan penaakulan pantun.

Keberadaan pantun-pantun "cukup elok" ini suatu kenyataan, dan keberadaan skop-skop logik pantun juga dapat dibina bukan atas sokongan khayalan. Maka pembinaan logik pantun secara horizontal yakni sebagai sebuah kajian bukanlah suatu masalah besar melainkan secara vertikal, iaitu sejarah logik pantun yang lebih rumit lagi mencabar. Pembinaan sejarah logik pantun menjadi rumit kerana ketandusan pantun-pantun "cukup elok" yang bertulis lagi bertarikh mengikut zaman. Biarpun pantun dikatakan "rangkapan yang tertua dan memang asal kepunyaan Melayu betul" (Za'ba, 2002: 223), namun pantun bertulis terawal diperoleh hanya selepas Hikayat Bayan Budiman (termuat dua rangkap pantun) dari 1371 M. Dengan erti kata yang ringkas, pembinaan sejarah logik pantun sebelum $1371 \mathrm{M}$ adalah tidak mungkin buat sementara waktu. Sejarah logik pantun selepas $1371 \mathrm{M}$ dapat dibina atas penggabungan dua kaedah, iaitu: 
Jadual 1 Kronologi karya-karya berpantun Melayu (sehingga Munsyi Abdullah). ${ }^{4}$

\begin{tabular}{|l|l|}
\hline Tarikh & Nama Karya \\
\hline 1371 & Hikayat B ayan Budiman \\
\hline$\sim 1390$ & Hikayat Raja Pasai \\
\hline$\sim 1450$ & Undang-Undang Melaka \\
\hline$\sim 1525$ & Hikayat Pandawa Lima \\
\hline$\sim 15 ? ?$ & Hikayat Seri Rama \\
\hline$<1600$ & Hikayat Inderaputra \\
\hline$\sim 1612$ & Sejarah Melayu \\
\hline 1625 & Cerita Kutai \\
\hline 1650 & Hikayat Bakhtiar Hikayat Tanah Hitu \\
\hline 1663 & Hikayat Banjar dan Kota Waringan \\
\hline$\sim 1700$ & Hikayat Hang Tuah \\
\hline$\sim 1720$ & Hikayat Syah Mardan \\
\hline$\sim 1750$ & Syair Bidasari. Hikayat Panji Kuda Semirang \\
\hline$\sim 17 ? ?$ & Hikayat Putera Jati Jaya \\
\hline 1750 & Syair Hemop \\
\hline$\sim 1780$ & Misa Melayu \\
\hline 1788 & Hikayat Nakhoda Muda \\
\hline$\sim 1800$ & Hikayat Raja Bikrama Sakti. Syair Siti Zubaidah Perang China \\
\hline 1811 & Hikayat Perintah Negeri Benggala \\
\hline$<1821$ & Syair Sinyor Kosta \\
\hline$\sim 1830$ & Syair Kerajaan Bima \\
\hline 1838 & Pelayaran Abdullah ke Kelantan \\
\hline$\sim 1840$ & Hikayat Marakarmah (Hikayat Si Miskin) \\
\hline 1844 & Hikayat Maharaja Marakarma \\
\hline 1849 & Hikayat Abdullah bin `Abdul Kadir \\
\hline$\sim 1850$ & Syair Sunur \\
\hline & \\
\hline
\end{tabular}

i) Kaedah pengumpulan: ceritera-ceritera, hikayat-hikayat dan lain-lain karya tradisional Melayu yang termuat rangkap-rangkap pantun dikenal pasti dan dihimpunkan (contoh, Noriah, 2015); 
ii) Kaedah pentarikhan: pantun-pantun himpunan dikronologikan menurut tarikh penulisan atau perawian ceritera-ceritera, hikayat-hikayat dan lainlain tersebut atas (contoh, Iskandar: 1995);

Dengan penggabungan kaedah ini, pantun yang dirawikan pada tahun $1371 \mathrm{M}$ (seperti Hikayat Bayan Budiman) sudah tentu tidak boleh dikelirukan pentarikhannya dengan pantun yang termuat dalam karya penulisan dari 1612 M (contoh Sejarah Melayu). Begitu juga dengan pencapaian penaakulan pantun berkenaan hendaklah dinisbahkan kepada zaman perawian atau penulisannya masing-masing dan tidak boleh dikelirukan. Dengan demikian sejarah logik pantun Melayu dapat dibina berdasarkan karya pantun berkronologi seperti Jadual 1.

Dengan erti kata yang lain, apabila penilaian karya pantun menurut pendekatan penaakulan dilakukan secara berkronologi seperti Jadual 1, pensejarahan penaakulan pantun sekali gus logik pantun dapat dibangunkan atas landasan yang kukuh lagi meyakinkan. Pengkajian mengikut kronologi ini juga akan membantu kita melihat pola serta evolusi penaakulan pantun secara mengkhusus dan logik Melayu secara umum sepanjang 650 tahun yang lalu semenjak $1371 \mathrm{M}$, iaitu bermula daripada pantun bertulis terawal yang telah dikumpulkan.

Sejarah bertulis logik pantun Melayu sebelum $1371 \mathrm{M}$ memang tidak semudah untuk dibina. Hal ini adalah disebabkan pantun bertulis sebelum $1371 \mathrm{M}$ itu masih belum dapat diperoleh, di samping bahan-bahan bertulis lain yang menunjukkan bahawa orang Melayu berpuisi dalam bentuk gatha (Buddha) atau seloka (Hindu) semenjak kurun ketujuh dari zaman Srivijaya. Suatu kajian terkini menunjukkan bahawa gatha gubahan Srivijaya mempunyai persamaan dengan pantun zaman sekarang dalam, iaitu berbaris empat, sesetengah terdiri daripada dua unit dan berhubungan analogi seperti mana pantun yang kita huraikan sebelum ini (Tee, 2020). Jadi masalah terpapar di hadapan kita ialah apakah gatha Srivijaya adalah genre prapantun Melayu yang bakal mengisi sejarah logik (gatha-pantun) Melayu sekitar 671 M-1371 M iaitu 700 tahun sebelum daripada pantun bertulis terawal yang kita sebutkan itu? 


\section{NOTA}

1 Semua contoh pantun diambil daripada Zainal Abidin Bakar (1983) dan nombor asal dinyatakan berkurung pada akhir setiap pantun.

2 Pendekatan lain termasuk makna unit maksud ditafsirkan menurut keilmuan makrifat yang dikatakan bertingkatan, maka angka-angka empat, tiga diperkirakan berhubungan. Hal ini memang suatu perkara biasa menurut Mohd. Taib Osman, iaitu pentafsiran sesetengah hubungan pembayang-maksud adalah "terpulang kepada tanggapan kita sendiri" dan "perkara seperti ini dapat dibincangkan tanpa satu keputusan yang muktamad.” (1975: 8)

3 Hassan Ahmad mungkin tidak bermaksud untuk Za'ba (Zainal Abidin Ahmad) yang telah membahaskan bahasa kiasan dalam bab 11, Ilmu Mengarang Melayu (2002: 195-210). Perbahasan Za‘ba tidak menjurus kepada jumlah serta jenis-jenis bahasa kiasan Melayu melainkan suatu pembahasan dan pengelasan umum tentang bahasa tersebut.

4 Lihat penjelasan pentarikhan bagi setiap karya daripada: Malay Concordance Project, http:// mcp.anu.edu.au/Q/texts.html\#chronological. Tanda “〜” adalah untuk maksud "sekitar" dan “<” adalah "sebelum" tahun pentarikhan.

\section{RUJUKAN}

Hassan Ahmad (2016). Bahasa dan pemikiran Melayu (Pesanan terakhir pejuang bahasa). Dewan Bahasa dan Pustaka.

Holyoak, K. J. (2012). Analogy and relational reasoning. The Oxford handbook of thinking and reasoning (pp. 234-259). Oxford University Press.

Teuku Iskandar. (1995). Kesusasteraan klasik Melayu sepanjang abad. Jabatan Kesusasteraan Melayu, Universiti Brunei Darussalam.

Harun Mat Piah. (1989 / 1997). Puisi Melayu tradisional: Satu pembicaraan genre dan fungsi. Dewan Bahasa dan Pustaka.

Harun Mat Piah. (2007). Pantun sebagai artifak budaya. Universiti Pendidikan Sultan Idris. Needham, J. (1998). Science and civilisation in China: The social background. Language and logic in traditional China. Volume 7 Part 1.. Cambridge University Press.

Mohd. Taib Osman. (1975). Warisan puisi Melayu. Dewan Bahasa dan Pustaka, Kementerian Pelajaran Malaysia.

Muhammad Haji Salleh. (2016). Ghairah dunia dalam empat baris: Sihir pantun dan estetikanya. Institut Terjemahan \& Buku Malaysia.

Mohd. Rosli, S. (2007). Seni berpuisi. Goal Intelligent.

Spangler, M. M. (1987). Logic: An Aristotelian approach. University Press of America.

Street, T. (2004). Arabic Logic. Handbook of the History of Logic. Greek, Indian and Arabic Logic. , Volume 1. (pp. 523-596). Elsevier.

Noriah Taslim (peny.). (2015). Pantun perawi. Penerbit Universiti Sains Malaysia.

Tee, B. C. (2020). Logik Buddha zaman Srivijaya dan dampaknya terhadap pantun Melayu. Melayu: Jurnal Antarabangsa Dunia Melayu, 13(1), 133-160. 
MELAYU: JURNAL ANTARABANGSA DUNIA MELAYU JILID 14 BIL. 2 JULAI 2021

Tittle, P. (2011). Critical thinking: An appeal to reason. Routledge.

Satis Chandra, V. (1921). A history of Indian logic: Ancient, mediaeval and modern schools. Calcutta University.

Za‘ba. (2002). Ilmu mengarang Melayu (Edisi Ejaan Rumi Baharu). Dewan Bahasa dan Pustaka.

Zainal Abidin Bakar. (1983 / 2018). Kumpulan pantun Melayu. Dewan Bahasa dan Pustaka. 